\title{
Coalescence and the Fiction of Iain Banks
}

\section{David Leishman}

\section{(2) OpenEdition}

1 Journals

Electronic version

URL: https://journals.openedition.org/etudesecossaises/208

DOI: 10.4000/etudesecossaises.208

ISSN: 1969-6337

\section{Publisher}

UGA Éditions/Université Grenoble Alpes

\section{Printed version}

Date of publication: 30 April 2009

Number of pages: $215-230$

ISBN: 978-2-84310-138-0

ISSN: 1240-1439

\section{Electronic reference}

David Leishman, "Coalescence and the Fiction of lain Banks", Études écossaises [Online], 12 | 2009,

Online since 30 April 2010, connection on 11 April 2023. URL: http://journals.openedition.org/

etudesecossaises/208 ; DOI: https://doi.org/10.4000/etudesecossaises.208

All rights reserved 


\section{Coalescence and the fiction of lain Banks}

Iain Banks's second novel, Walking on Glass, seems to be ideally suited for the 2007 SAES conference theme of "l'envers du décor" or "behind the scenes", since it is preoccupied with the exploration of literature's mechanisms and workings and with the frontiers of fictional worlds. All this is foregrounded in the novel's incipit. The opening paragraphs are dominated by the colour white as if to reaffirm the ultimate liminality of the text, the presence of the blank page that lies permanently beneath (p.11). Meanwhile, an incongruous character has opened up a service hatch in the (white) floor and is scrabbling about inside with a torch, the unfamiliar conduit leading to hidden levels and unimagined apparatus that defamiliarise the surface reality and challenge its seamlessness. The text precisely specifies the time as being " $3: 33$ " and this trinity is presented by the narrator as a "good omen", portentous of "a day events would coalesce" (p. 11), thus announcing the novel's central concern with the inter-connection between different ontological spheres.

In addition, the number three, repeated three times, necessarily evokes a theatrical universe through allusion to the unities of dramatic convention, a tripartite dramatic structure or the knocks which announce the imminence of a performance. As if to confirm this reading, on the following page the lead character, Graham Park, steps into the brightness of day and contrasts the intensity of the moment with duller times where events were like "actors fumbling behind some thin stage curtain, struggling to get out" (p. 12). Later Park's friend Slater is described as an actor playing a part (p. 191), while in a purportedly separate narrative, the narrative describes a curious castle whose attendants remain hidden by the mask of Greek tragedy (p. 42). Through these theatrical allusions Banks's text clearly sets itself up as a spectacle, readily admitting the showmanship and behind-the-scenes activity that this entails.

What this paper aims to do is to take the novel Walking on Glass as the central example of a strong self-reflexive current in Iain Banks's fiction in order to question the ideological consequences of such metafictional, postmodernist elements in his writing. The image of an author exerting 
absolute, God-like power over the fictional worlds he creates has led him to be portrayed by critics as an inveterate player of games. ${ }^{1}$ It is nevertheless my intention to challenge the common charge that postmodernist writing, through its constant game-playing and its eagerness to draw attention to its own artifice, refuses to engage with the real.

Iain Banks is one of Scotland's most prolific and best-selling authors of recent years, publishing a near annual stream of novels since The Wasp Factory first appeared in 1984. Though the name Iain $M$. Banks is reserved for his science fiction output, this division is somewhat misleading since the oeuvre of the supposedly more mainstream Iain Banks is characterised by its tendency to transgress traditional genre boundaries, notably interweaving science fiction and fantasy modes with more realist fiction. ${ }^{2}$ This is particularly true in novels such as The Bridge (whose debt to Lanark was openly admitted by Banks, as has often been noted), and also Walking on Glass (1985). The latter, Banks's second to appear in print, was nevertheless written prior to The Wasp Factory, and a version of it came close to being published in 1979, this anteriority reaffirming its place as one of the founding texts of Banks's literary oeuvre. ${ }^{3}$ The Bridge oscillates between two fictional universes, one science fantasy, one realist, although the novel nevertheless contains numerous connections between the two narratives.

The earlier novel, Walking on Glass, presents a similar structure, but in place of The Bridge's bipolar ontological structure, it contains three intricately bound but initially separate narratives. The first is focused on an amorous art student, Graham Park; the second on the deluded Stephen Grout, who believes himself to be a futuristic warrior marooned in 1980s London; the third on Quiss and Ajayi, a pair of just such futuristic warriors imprisoned in a castle standing on a barren planet. These characters are, at a structural level, presented as inhabiting discrete universes since the novel's architecture, in all but the final section, is composed of sections where the three worlds alternate, each allocated a separate, named chapter in strict succession.

1. For an additional metafictional twist, Alan Riach names Banks "The Player of Games" after his 1988 novel of the same name. Alan Riach, "Nobody's Children: Orphans and their Ancestors in Popular Scottish Fiction after 1945", Studies in Scottish Fiction: 1945 to the Present, Susanne Hagemann (ed.), Frankfurt, Peter Lang, 1996, p. 66-72. See also Thom Nairn, "Iain Banks and the Fiction Factory", The Scottish Novel Since the Seventies, Gavin Wallace and Randall Stevenson (eds.), Edinburgh, Edinburgh, University Press, 1993, p. 130; Alan MacGillivray, "The Worlds of Iain Banks", Laverock, $\mathrm{n}^{\circ}$ 2, 1996, reprinted at http://www.arts.gla.ac.uk/ScotLit/ASLS/Laverock-Iain_Banks.html [online resource], consulted March 2007.

2. Thom Nairn, "Iain Banks and the Fiction Factory", p. 127.

3. Chris Mitchell, "Getting Used To Being God", http://www.spikemagazine.com/0996bank. htm [on-line magazine], consulted March 2007. 
On the other hand, much of the novel's energy and interest comes from the increasing porosity between these worlds in the form of textual echoes, parallels, embeddings and inter-connections. In the final section, a single chapter entitled "Truth and Consequences", we are offered a promise of resolution which, the reader assumes, will be achieved by ensuring the separate ontologies converge into one definitive truth. Katherina Dodou has noted, however, that this is nothing but a quasi-conclusion, which destabilises our desire for closure by refusing to acknowledge a single dominant reality among the three separate ones offered. ${ }^{4}$ Worse still, the novel's internal paradoxes are said to render these separate realities - as formed by the Park, Grout and Quiss/Ajayi narratives - mutually exclusive, so that not only a sense of hierarchy between the different ontologies is challenged, but also their compatibility and capacity to form a coherent whole. As Dodou observes, the ending shows both the paranoid Grout chapters and the realist Park chapters to be contained within the far-flung science fiction fantasy of the Quiss/Ajayi narrative while concurrently undermining this ontological dominance by proposing the Quiss/Ajayi narrative to be nothing but the deluded imaginations of a now amnesiac Stephen Grout.

Thus the perfect trinity announced in the incipit has been not a "good omen" but a false portent; instead of achieving coalescence, the three narratives remain an impossible mismatch of parasitical and competing truths. The ending of the novel, according to this interpretation, is of particular importance since it is this resistance to solving the central enigma that establishes the endemic uncertainty described by David Lodge as a key feature of postmodernist writing. ${ }^{5}$ Just as the paranoid Stephen Grout is constantly frustrated in his attempts to find the hallowed "Way Out", the "key" to escape his suffering in a universe of artifice, so the reader is denied a satisfying literary exit.

Studies on Walking on Glass and The Bridge, such as those by MarieOdile Pittin-Hédon or Thom Nairn have analysed with interest how the complex embedding of different diegetic levels, the use of textual and intertextual echoes, the foregrounding of typography, all contribute to forming irreducibly playful, self-referential narratives whose key characteristic is their pervasive ambiguity. Their resulting multiplicity corrupts and destabilises literary conventions as the texts show the breaching of perceived barriers between separate and stable ontologies, narratives, genres, identities, chronologies and so on. However, in such a view, one

4. Katherina Dodou, "Evading the dominant 'reality' - the case of Iain Banks's Walking on Glass", Studia Neophilologica, vol. 78, n 1, June 2006, p. 28-38.

5. David Lodge, The Modes of Modern Writing, London, Edward Arnold, 1977, p. 226. 
final bridgehead remains unassailable. As Lyotardian "grand narratives" such as order and truth are overthrown in favour of postmodernist doubt and subjectivity, the barrier between the text and our world, the literary and the extra-literary spheres, initially seems all the more secure. With their spiralling, narrative self-reflexivity, their looped chronologies, their endless intertextual playfulness, such novels seem to be vocally asserting a militant textuality that has two chief consequences.

The first is seemingly to underline their distance from the universe of the non-literary real. Speaking in particular of The Bridge, Thom Nairn describes how the effect of the palimpsests in Banks's fiction is one of creating "wheels within wheels, veneer beneath veneer" ": the answer to the question of what lies behind the text, is simply that of a vertiginous series of further texts; behind the sign lie yet more signs. Thus, in this reading, an "ontological cordon sanitaire" 7 is set up around the fictional text, since no definitive link between the word and the world can be positively construed.

Secondly, through their dissemination of multiple, contradictory narratives such works can be seen as highlighting the role of discourse in constructing our perceptions of reality and truth (a point we shall return to later). Marie-Odile Pittin-Hédon has analysed such trends in the work of Iain Banks and Alasdair Gray and noted how the destabilising postmodernist elements lead to a complexification of their fiction's political or ideological elements. ${ }^{8}$ But beyond this, if the realist narrative is ultimately inseparable from the science fiction narrative in The Bridge, leading to the impossibility of determining a principal ontological level, ${ }^{9}$ the militancy of the novel's political subtext, - that of Orr's leftwing idealism corrupted by his complicity in the oil and defence industries in Thatcher's Britain - can appear ultimately weakened. In the novel, Scotland's 1979 devolution referendum, the exploitation of North Sea Oil to finance Tory reforms, Cold War fears of atomic annihilation appear to be placed on the same level as the sci-fi cityscape of "the Bridge", whose irreality is highlighted by its infinite construction, its sudden appearances and disappearances and its ambient amnesia. Rather than merely complexifying political themes, such ontological fusing seems to justify postmodernism's

6. Thom Nairn, "Iain Banks and the Fiction Factory", p. 131.

7. Brian McHale, Postmodernist Fiction, London - New York, Routledge, 1987, p. 34.

8. See Marie-Odile Pittin-Hédon, "Iain Banks. Culture(s): l'écriture éclatée", Études écossaises, $\mathrm{n}^{\circ}$ 6, 2000, p.211-212; Marie-Odile Pittin-Hédon, "Alasdair Gray: Le piège de la dialectique", Études écossaises, $\mathrm{n}^{\circ}$ 8, 2002, p. 75-87.

9. Marie-Odile Pittin-Hédon, "Versions of the truth disseminated': L'irrationnel chez Iain Banks", Etudes écossaises, n 9, 2003/2004, p. 308. 
reputation for promoting a handicapping relativism, logically accompanied by a retreat from the political arena.

Banks's adoption of postmodernist techniques perhaps contributes to his ambiguous image as a politically-engaged author of apolitical fiction. In interviews Banks proved himself an outspoken critic of the Conservative Party in the 1980 s and 1990 s, ${ }^{10}$ yet his fiction has simultaneously been described as being conspicuously detached from the socio-political concerns of many of his peers. ${ }^{11}$ Commentators seem undecided as to his work's ideological tenor: his fiction is described as populist story-telling, but is also said to be underpinned by a "social conscience". ${ }^{12}$ In one interview, Banks is attributed as saying that he is not a political writer, with The Business then being cited as a counterexample. ${ }^{13}$ Complicity's all-out attack on the values of Thatcherism or the geopolitical intrigue of Canal Dreams are similarly presented as exceptions to the rule. ${ }^{14}$ It is, however, possible to interpret the postmodernist impulses of Walking on Glass in a way which, without destroying their insistence on ambivalence and duality, reconciles textual game-playing with Banks's evident political concerns.

Few novels in Banks's large repertory are more easily assimilable to the mode of postmodernist playfulness than Walking on Glass. The trope of game-playing is a central element in the novel's construction and cohesion, linking the thematic level (the series of near-impossible games that Quiss and Ajayi play and the subsequent paradoxical riddle they must then attempt to solve); and the narrative level (every third chapter is named after such games: "One-Dimensial Chess", "Spotless Dominoes" etc. highlighting growing narrative tension with each successive attempt and failure). More fundamentally, the novel's broader narrative structure is composed of six numbered sections, thus mimicking the faces of a dice and undermining the entire text by placing it under a potent symbol of probability and chance. The problematics of text-as-game is furthered by the fact that the games played by Quiss and Ajayi - chess, go, dominoes, scrabble - all feature pieces which are black and white. Their monochrome nature has an evident mimetic function, mirroring

10. Kate Kelman, "A Collision of Selves", Cencrastus, n 60, n. d., p. 19.

11. Marie-Odile Pittin-Hédon, "Iain Banks. Culture(s): l'écriture éclatée", p. 211-212.

12. Liz Hoggard, "Iain Banks: tbe novel factory", The Independent, 18/2/2007, reprinted at http://www.independent.co.uk/news/people/iain-banks-the-novel-factory-436865.html [on-line newspaper], consulted March 2007.

13. "Banks' Business interests", 14/08/1999, http://news.bbc.co.uk/1/hi/entertainment/419517 .stm [on-line resource], consulted March 2007.

14. Richard Tallaron, "Iain Banks", Études écossaises, n³, 1996, p. 143-144. 
the black and white of the type-written page, a link which is made more explicit by Quiss's Borgesian discovery that the castle in which they are imprisoned is in fact composed of text. When eroded, the slate-like rock with which the castle is built reveals the following:

a series of cut or engraved figures [...], arranged in lines and columns, complete with word breaks and line breaks and that looked like punctuation. Quiss had demolished a significant part of the castle when he first discovered this, unwilling to believe that the stones, every one of them, all the tens of thousands of cubic metres the castle must be composed of, all those kilotonnes of rock were really saturated, filled full of hidden, indecipherable lettering. (p. 38-39).

Similarly, as a form of insulation, the castle walls are lined with equally obscure "paper and cardboard books" written in unknown languages (p. 45). As the games they have to master degenerate further into frustrating randomness, such as the game "tunnel" played with blank cards, game-playing becomes a vain search for meaning in a disquieting universe of effaced signs and incomprehensible texts. But beyond that troubled search for meaning lies nothing but oblivion. The castle is surrounded by endless snows; when Quiss, weary of playing futile games, contemplates suicide it is by jumping from the castle parapets to the "white plain" below (p. 218).

The domination of black and white - and, as a corollary, the omnipresence of print - is continued in descriptions of setting and character in the other narratives, creating thematic continuity between them. In the Grout narrative, the paranoid character's bed-sit mirrors the castle's architecture since the great many fantasy and sci-fi books he reads to find the "Key" to his existence are arranged in piles that form a maze of walls and tower-blocks (p. 30). His lodgings also contains a black and white television, a "monochrome set" (p. 107), and a cassette player on which he listens to the "static" - the white noise - which he interprets as a "Leak" affording him a glimpse of reality (p. 113). The "Evidence box" in which he collects the clues to what he imagines as his true identity is "an old Black and White whisky case" (p. 113). In the first narrative, Park appears to the reader carrying a "black portfolio" then walks along the white corridors of his art college and past the "White Hart" pub (p. 11). When he later enters another pub called the "White Conduit" (p. 153), the text reveals another wormhole in its structure, proof of its desire to unselfconsciously foreground its own internal workings. Park's own physical appearance incongruously binds black and white together: "snowwhite shirt, black jacket, white trainers and lightly-blonded dark hair" (my italics, p. 51). When describing Park with Sara, his would-be girlfriend, 
the text goes beyond the logic of the oxymoron to present black and white as if they were two oppositely charged particles which, if coalescence is achieved, can but lead to obliteration:

He held her, but he felt nothing; [...] a silent mix of identities cancelled out, like the pale skin, white scar, dark clothes and black hair being equated and combined, and the resulting coalescence being clear, invisible... nothing. (p. 67)

Rather than an unrevealing moral reading of this interplay of black and white (Sara as evil, Park as innocence), it is tempting to see this passage as an ironic comment on the text's own postmodernist hollowness. The novel's creative prowess is in its near-coalescence - the construction of multiple conduits between three complex, disparate narratives in order to twist them into a unified, but paradoxical, single ontological sphere - but if we take the description of Sara's evanescence as a metaphor it may suggest that such flourishes are nothing more than literary parlour tricks, which, if challenged, reveal themselves to be mere smoke and mirrors: once the aporias, the bloated intertextuality, the convoluted narrative echoes are catalogued, might there lie no further substance or meaning?

The three narratives do come together in such a way as to suggest a cancelling out. Park and Grout form the basis of two structurally distinct narratives, but clearly evolve and even indirectly interact in the same ontological sphere (Grout causes Slater to be late for his meeting with Park by putting sugar in his petrol tank; Park comes across the remains of the incident with Grout by the canal). Quiss finally learns that the mysterious castle where he has been imprisoned is situated on earth a billion years after the decline of humanity, hence its name as the "Castle of Bequest" (p. 167), suggesting again a separation with the Park/Grout narratives that is chronological, but not ontological, in nature. The proximity between the two narratives is then intensified as Quiss discovers a chamber full of telepathic conduits which allow the prisoners of the castle to experience the lives of the former inhabitants of earth, thus also overcoming any chronological separation between the two spheres. It is here that Quiss encounters a character whose imprecise, emptily intertextual name "Godot? Goriot? Gerrut" (p. 227) alludes to the fact that Grout too is indeed fully part of this futuristic, fantastic universe, as he believes himself to be.

In this same universe, Ajayi finally masters English, one of the hitherto obscure languages in the books which make up the castle, and she ends the novel as she begins to read an untitled work whose incipit is that of Walking on Glass. Typically postmodernist in its foregrounding of textual conventions and in its insistence on ontological uncertainty, this 
metaleptic intrusion situates the characters (Park and Grout, although presumably also Ajayi and Quiss) as the products of a (fictional) text, which not only destroys the realist effect but also undermines the novel's chronological integrity. The effect of such a mise en abyme is to fix ending and incipit together as a never-ending loop, an ouroboros chronology which, tail in mouth, consuming itself, again shows coalescence as annihilation and defies any logical grasp of causality, history or progression.

But the text also concurrently suggests that Quiss and Ajayi, their castle, their frustrations are merely distorted echoes of Grout's perceptions, thus placing the science fiction diegesis as subordinate to the realist in a further ontological complication. Grout, now confined to the grounds of a sprawling hospital, observes two aged patients, one male and one female, whose games of chess, dominoes and scrabble are constantly disrupted by another patient who frustrates them by stealing their pieces, such as the one shaped "like a little castle" (p. 216).

In this reading, the novel's intertextuality becomes another example of the endlessly deferred meaning which would appear to confirm postmodernism's superficiality. Indeed, in addition to the otherwise incongruous references to Beckett or Balzac previously mentioned, Walking on Glass noisily draws attention to its antecedents: Borges' Labyrinths, Mervyn Peake's Titus Groan, Kafka's The Castle, which all appear as tightly rolledupped texts compressed inside the structure of Quiss and Ajayi's games table (p. 232), thus forming part of the physical composition of the Castle of Bequest, just like the countless other nameless works found in the rock or cladding that make up the edifice. In this way, the endless library-world of Quiss and Ajayi unselfconsciously reveals its Borgesian archetype, the "Library of Babel" from the short story collection cited providing the key image of a perfectly inescapable heterocosm of text. Meanwhile, the Castle of Bequest's Byzantine ritual, strict hierarchy, busy kitchens and sprawling architecture are all very closely copied from Peake's closed castle-world of Gormenghast.

In the narrative which focuses on Stephen Grout ${ }^{15}$ a final intertextual element again seemingly underlines the vacuity of all this: Grout, now amnesiac and set to remain within a secure hospital for the rest of his days, ${ }^{16}$ discovers the answer to the riddle that has eluded Quiss and Ajayi printed on the back of an abandoned, spent box of matches. The matchbox has the brand "McGuffin's" printed on it, the intertextual

15. The name seems to be an alliterative acknowledgement of Peake's influence, one of the central characters in the Gormenghast series being Titus Groan.

16. A fate at variance with the hidden meaning ("Ger-out!", p. 217) revealed as the crows caw his onomatopoeic name. 
reference relating to Hitchcock's (felicitously Scottish) fetish term for an artificial element of plot which serves little purpose other than advancing the intrigue. Hence the key to Quiss and Ajayi's escape turns out to be a self-referential symbol of narrative superficiality. The contents are also said to contain $\sqrt{2}$ matches. Since the square root of two is an irrational number which repeats infinitely after the decimal point this is another powerful symbol of irresolution and the endless deferment of meaning. This endless stream of numbers forms a link with the Quiss/Ajayi narrative, where at the heart of the castle lies a literalised "number cruncher" (p. 171-173), an elaborate contraption where giant replica numbers are created from plaster and then ground up only to be re-formed and crushed again in a perpetual cycle of destruction and rebirth. This literary pun unites a final instance of textual game-playing with the tropes of ceaselessness and containment to form a central statement about the tenor of the novel.

Nevertheless, it is this same numerical reference $(\sqrt{2})$ which begins to shift the emphasis away from the interpretation of the novel as a maddening series of inane postmodernist pranks. The square root of two, presented approximately as the ratio of $1: 1.4$, is the origin of the most commonly used norm for the dimensions of paper such as A2, A3, A4 etc. The matchbox formula thus subtly again leads us back to the frontiers of the text by reaffirming the role of paper as the physical continuum between the fictional and extraliterary universes. No fictional world can remain a perfect heterocosm, no matter how convoluted its invented ontologies, since the text is invariably, ultimately printed on a real-world physical medium. The (often white) conduits, tunnels, passages and exits that haunt the novel point not only to the layering of different intradiegetic, ontological levels but also to the final conjunction between the world of text and our physical world of the extradiegetic real.

One aspect of self-reflexive postmodernist texts, in the manner of the much-discussed comment in Lanark that the world is composed not of atoms but of print (Lanark, p. 485) is to foreground the problematic relationship between these worlds. Linda Hutcheon insists that postmodernism represents not the renouncement of truth and reality that has been much decried, and insists instead that while truth, the past and reality certainly exist, we only have access to them through the mediation of language, discourse and texts. It is this which necessitates an awareness of the politics of representation, and thus an acceptance of the power of fictional texts to model the extraliterary. ${ }^{17}$ Thus the theme of coalescence in the novel

17. Linda Hutcheon, A Poetics of Postmodernism, London - New York, Routledge, 1988, p. 40. 
cannot be confined to the diegetic sphere. It forces us to re-examine the previous notion of a hermetically-sealed fictional universe signalling its autistic retreat from the real by means of its obsessive textuality.

The intertextual references in Walking on Glass can thus be re-examined in light of Hutcheon's political reading of postmodernism. The narrative thrust of Titus Groan is the chaotic disruption of Gormenghast's timeless court rituals as an alien element, the scheming kitchen-boy Steerpike, insinuates himself into the closed world of the Groan dynasty. The metafictional comment here seems to be that the heterocosm is an illusion, always susceptible to being breached, if by trickery rather than by force.

Kafka's The Castle always seemed an uninspiring antecedent if Quiss and Ajayi's inability to escape a snowbound castle was simply understood as the mirror image of K's incapacity to enter such a structure. More rewarding is an appraisal of the power of discourse in Kafka's novel, as evidenced by the importance of messengers, documents, rumours and complaints in determining K's fate. In The Castle it is this anarchic communication, in the image of the inn's dangerously unpredictable telephone, which mediates relations between the semi-closed physical worlds of the village and the castle.

If we take Grout's labyrinth of paperback novels or Quiss and Ajayi's castle of books as symbols of inescapable palimpsests, the allusion to Borges' "Library of Babel" can function as another motif of textual containment. Nevertheless, Banks's images of these worlds (whether manmade microcosm or natural macrocosm) whose architecture and geology are composed of texts, also symbolise the continuum that irredeemably links the written word and the real and literalise the notion of physical realities being constructed on the linguistic foundations of texts and discourse. Thus the key text from Borges' Labyrinths by which to read Walking on Glass is perhaps rather "Tlön, Uqbar, Orbius Tertius", which, through its depiction of a spurious world being catalogued in a real-world encyclopaedia, reinforces the central theme of the permeability between the worlds of imagination and physical reality.

Another element of intratextual and intertextual coalescence - which stands apart from the canonical references to Kafka or Borges - continues to weaken the charge of postmodernist vapidity. The Park and Grout narratives are connected through Douglas Adams'science fiction series, The Hitch-Hiker's Guide to the Galaxy. Whereas Grout appears as a misguided hierophant, perceiving such fiction as containing the clues to a veiled reality just beyond his ken and attempting to glean clues to his existence from the mysteries they hold, Park tends to look down on such works and involuntarily grounds them in the mundanities of everyday 
existence. A curiously familiar character name from Adams' novel particularly intrigues Grout (p. 30) and later this name turns up again, connected to a piece of "estate agent's literature" that forms part of his "evidence" about the world he believes to lie beyond the one he perceives (p. 113-114). Later Park picks up two books from Douglas Adams'series and reflects in passing that the name for the character Hotblack Desiato was in fact simply lifted by Adams from a chain of London estate agents. This intrusion of extraliterary reality into the most exuberant of fictional universes seems to confirm the sense of an open conduit between the two spheres. Walking on Glass then literalises such a connection in a scene again heavily influenced by Douglas Adams. When Quiss is shown the millions of telepathic conduits between his era and our own it is in a vast, geometry-defying basement that lies under the castle. The twisting of space and scale results in a circular room so immense that the curve of the walls is only faintly perceptible, the far wall disappearing over the horizon. This is a close parallel of the scene in The Hitch-Hiker's Guide to the Galaxy which describes the manufacture of planets, including our Earth, in a vast "room" of stellar dimensions:

His eyes could not accept it; his brain took in the short space between floor and ceiling and so expected walls, expected a room-space. But if he was in a room $[\ldots]$ then its walls appeared to be somewhere over the horizon. [...] He looked along the very slightly curved wall, trying to estimate the diameter of the circle it implied. (Walking on Glass, p. 223)

The wall defied imagination [...] The wall was so paralysingly vast and sheer that its top, bottom and sides passed away beyond the reach of sight. $[\ldots]$ The wall appeared perfectly flat. It would take the finest laser measuring equipment to detect that as it climbed, apparently to infinity, as it dropped dizzily away, as it planed out to either side, it also curved. In other words the wall formed the inside of a hollow sphere [...] (The Hitch-Hiker's Guide, p. 122)

In addition to echoing Grout's dismissal of the Earth's authenticity - "ridiculous attempts to design a reasonable-looking planet" (p. 114) where one of the landforms looks like "a letter from an alien alphabet" (p. 115) - the scene in Adams' novel functions as a literalisation of the construction of physical worlds from fantastic fictional elements. Together, these references to elements of Adams' work reinforce the notion of a postmodernist continuum where the literary is forever grounded in the extraliterary and vice versa.

On close reading, the irreverent textual playfulness of Walking on Glass appears eager to underline its grounding in the sphere of socio- 
economic and political history. In the Park narrative, Sara, the object of Park's desire, goes by the assumed surname "ffitch", whose improbable double consonant and fussy lower-case spelling (corresponding in fact to the accepted typographical form of an existing real-world surname) is carefully justified in the text with a simile that refers to the economic and industrial difficulties of the early 1980s: "Not one big 'f'; two little ones. Like British industry, our Sara's under-capitalised.” (p. 97)

Indeed, a precise sense of historical context is achieved throughout by references to specific dates. While Grout's amnesia is discussed on February $16^{\text {th }} 1984$ (p. 212), Park's walk across London to meet Sara, coinciding with Grout's accident, are stated as having happened the previous year, on June $28^{\text {th }} 1983$ (p. 11), thus locating the novel's central narrative in the weeks following Margaret Thatcher's second election victory. This careful grounding in Thatcherite Britain is of prime narrative importance since the enigma of Sara and Slater's deception is explained by the fact that their father is a Conservative MP whose career, founded on promoting family values, would suffer immoderately if it was discovered that his children were conducting an incestuous affair (p. 207). With the election now over (and their father having lost his seat despite a Conservative landslide) their subterfuge can now end (p. 208).

We encounter some typically Banksian characters fond of knee-jerk anti-Conservative rhetoric - "Mag the hag", "reactionary moralist nonsense" (p. 207), "the old fascist" (p. 208), but this political strand to the narrative is tied to wider epistemological concerns about the nature of discourse, opinion and belief. Sara's declaration to Park of "the truth" (p. 199) about their relationship is a fabrication, in terms of both content and form (the narrative itself aware of its "falsity" and the formulaic nature of its rhetoric, due to such scenes being "portrayed in this popular culture a thousand times", p. 199-200). When Slater then supplants Sara's version, by writing a fuller confessionary letter to Park to explain the incestuous affair, it is significantly on the back of "an old Labour election leaflet" (p. 206). But rather than "the whole truth" that Slater promises, the palimpsests suggest texts and truths as uncertain, temporary constructs: just as the political discourse in the Labour leaflet is rendered null and void by a Conservative election victory, so too is Slater's "truth" silenced as he crumples what he has jotted down on the election leaflet and throws it in the waste-paper bin (p. 209). Authorial power to create and efface discourse underlines the fragility of perceptions of truth and reality - the contents of the metadiegetic text will be known to the extradiegetic reader, but not to its intended addressee. Another facet of this theme is then announced by means of an intertextual reference to the film Citizen Kane. As Slater lets the crumpled leaflet fall out of his 
hands, he moans "Rosebud!" (p. 209), the closing line of Orson Well's epic portrayal of a press baron modelled on William Randolph Hearst. In this way the novel presents the newspaper industry as a possible locus of such rhetorical and ideological power.

Indeed, newspapers are frequently cited in the novel and their ability to form opinions and model perceptions of reality is, sometimes ironically, underlined. Grout believes more in the truth of fantasy literature than in the newspaper "Strange but True" cuttings that he collects - "supposedly True Stories which Steven could tell were complete nonsense" (p. 113) - while the later amnesiac Grout believes the year to be 1976, despite the presence of a "Daily Express dated Tuesday, March 18 ${ }^{\text {th }}$, 1980" lying at his feet (p. 215). The strength of Sara and Slater's parents' family-values Conservatism is associated with an uncritical adherence to the political narratives of the traditionalist right-wing press: "they weren't bad sorts [...] they just believed everything they read in the Daily Telegraph." (p. 96). When a copy of the Sun is described being blown along the street (p. 147) it precipitates an analeptic passage which returns to just before the 1983 election to focus on the harmful influence of Fleet Street, or the "open sewer at the bottom of Chancery Lane" (p. 149), whose dominant discourses are held responsible for largely refashioning public opinion. In particular the role of the Sun in buttressing working class support for the Thatcherite project is highlighted in relation to neo-liberal economic pragmatism or the wave of patriotism following the Falklands:

He reads the Sun on the bus every morning going to work. [...] If he spends half an hour each day shovelling shit into his brain, you can't expect his ideas to do anything else but stink, can you? (p. 150-151).

In addition to the dominant black and white thematic of colour that was noted earlier, the other colour that recurs frequently and creates connections between the various narratives is red: Slater's bow tie which lights up with red stones (p. 18) and matches the glowing red stone at the centre of the gaming table (p. 34); Sara's red shoes (p. 44) and jacket (p. 54) or the mention of "Red Lion Street" (p. 95) all evoke the colour of the talking red crow whose power, significantly, is linguistic in that it has the ability to taunt Quiss and Ajayi in the voice of past acquaintances (p. 39). Following the novel's allusions to the physical medium of paper, to the association between black and white and the printed word, and to the impact of newspaper rhetoric, it is perhaps not surprising that the novel's other key colour is that which traditionally symbolised the British tabloid press, the "red tops". Thus the colour scheme of the novel - frequently defamiliarised by references to Park's habit as a painter of constantly observing the smell, stains and flecks of colour around him (p. 49, 
p. 61, p. 98, p. 197) - incorporates the colour red as an integral element in its exploration of the power of discourse.

The novel's postmodernism does not then present the moral relativism and political apathy often decried (notably by newspapers such as the Daily Mail). Instead, by foregrounding its own textual, narrative and cultural fabrication, and by questioning the relationship between political power and the media, it confronts the constructed, conventional nature of the dominant discourses which inform our actions as citizens. Thus, despite its self-avowed affection for artifice, the novel still remains politically engaged, this admixture of seriousness and play matching the "ethical hedonism" attributed to one of the characters in the novel (p. 191).

Its rejection of Thatcherite policies, ${ }^{18}$ similar to much Scottish fiction of the 1980s, crystallises around the fear of nuclear destruction brought on by a gung-ho Thatcher-Reagan alliance. Prompted by the siting of UK and US nuclear missiles on Scottish sites (e.g. Faslane and the Holy Loch) this is presented in the text as an "annihilation we are fascinated with by but powerless to do anything about! Vote Thatcher! Vote Reagan! Let's all die! Yip-fucking-pee!" (p. 189). These Cold War fears of imminent nuclear destruction (see also p. 150), point to Park's final-scene pessimism about where human "progress" could ultimately take mankind and provide the backdrop for the third narrative's vision of a barren, lifeless planet, possibly the result of some "cataclysm"(p. 175). However, we can note in Park's comments that physical domination is inseparable from the rhetorical elements which underpin it, the text linking "the torturingly ingenious, carefully civilised savagery of the technology of pain and the economies of greed [...]" to the "hollow, ringing, bullshitting words used to justify and explain the utter howling grief of our own cruelty and stupidity." (p. 238). Language and discourse are presented as irremediably dual: as Park's disgust with the world becomes a physical retching, the tongue in his head is described as both "instrument of articulation" and "a great poisoned sac" (p. 238-239). The power of language to liberate at an individual level, (figured by Ajayi's success at accessing the castle's mysterious texts - "the castle was no longer the prison it had seemed before $[\ldots]$ ", p. 175), contrasts with its power to confine, by conditioning thought and behaviour, as evidenced by the pastiche of intolerant right-

18. The novel's textual games also play into this critique of Thatcherite discourse. The successive chapters entitled "Mrs Short", "Mr Sharpe" and "Dr Shawcross" (later named "Doctor Shock", p. 212) from the Grout narrative together form the phrase "short, sharp, shock". Rather than being simply another abstruse pop culture allusion (The Mikado, Dark Side of the Moon) this phrase was of course popularised by Home Secretary William Whitelaw to explain the 1979 Thatcher government's "tougher approach" to deterring criminals. 
wing discourses that inform Mr. Sharpe's bigoted world-view (p. 159162). In short, Walking on Glass stresses the need for awareness of the underlying ideological tenor of the discourses that surround us.

The political elements in Banks's fiction should therefore not be read as superficial or secondary, even if this is at variance with some of Banks's claims about his work. ${ }^{19}$ Rather, postmodernist fiction frequently stresses its inescapable grounding in a socio-political context, even if that makes its critique of that system complicitous ${ }^{20}$ just like that of Lennox in The Bridge. Just as Banks's fiction often concentrates on the permeability of near-closed systems ${ }^{21}$ (one can think of the peninsula setting of The Wasp Factory, the canal in Canal Dreams, the mountain kingdom of The Business) and the indirect communication between worlds (such as the abstruse morse-like telephony in Whit) so the inseparability of the literary and the extra-literary reaffirms the inevitability of each sphere informing the other. Such a model can be seen in Banks's admission that his fiction is a means by which he, modestly, can bring some influence to bear on the real world:

Like anybody else, I want to make the world a little more like the world I'd like to live in, sad though that is. So I put forward these ideas however subtly or cack-handedly to the extent that I can get away with it. The good thing about writing is that you can do this in a non-invasive, non-penetrative way, you're not telling people this is what they should do, you're just presenting ideas. ${ }^{22}$

The fear of nuclear holocaust conveyed in Walking on Glass finds its real-world expression in Iain Banks's long-running commitment against Trident, which has culminated in his participation in a year-long blockade of the Faslane submarine base. ${ }^{23}$ The novel's foregrounding of how the manipulation of discourses can underpin both political power and our perception of the truth was translated into direct political expression when Iain Banks protested against the UK Government's decision to go to war Iraq War by cutting up his passport and sending it to Prime Minister

19. Banks has said of The Bridge, for example, that the "political is not embedded in the context of the book. It's just really dialogue". James Robertson, "Bridging styles: a conversation with Iain Banks", Radical Scotland, n 42, December 1989 - January 1990, reprinted at http://www.futurehi. net/phlebas/text/interv4.html [on-line resource], consulted May 2007.

20. Linda Hutcheon, A Politics of Postmodernism, London - New York, Routledge, 1989, p. 2.

21. See Alan Riach, "Nobody's Children", p. 66.

22. Chris Mitchell, "Getting Used To Being God".

23. See http://www.faslane365.org/fr/writers_poets_journalists [website of Faslane 365 protest group], consulted March 2007. 
Tony Blair in protest ${ }^{24}$, or by figuring in a high-profile campaign to have him impeached over the issue. ${ }^{25}$ We can note that in such protests, or in his signing of the Scottish Socialist Party's "Declaration of Calton Hill" which, timed to coincide with the inauguration by the Queen of the new Scottish Parliament, promoted an independent Scottish Republic, ${ }^{26}$ Banks has contributed to the modern Scottish tradition of radical novelists who are vocal, political activists. ${ }^{27}$ By using his profile as a best-selling novelist to help leverage public awareness and media coverage for the causes he champions, Iain Banks continues to underline the coalescence of the literary and the extra-literary, illustrating once again how fictional worlds have the power to impinge on our own. In doing so, Banks gives a timely reminder that neither popular fiction nor the postmodernist mode necessarily represent a depoliticisation of our cultural space.

\section{Bibliography}

Adams Douglas, The Hitch-Hiker's Guide to the Galaxy, London, Pan, 1979. Banks Iain, The Wasp Factory (1984), London, Abacus, 1996.

-, Walking on Glass (1985), London, Abacus, 1990.

- The Bridge (1986), London, Abacus, 1996.

-, Canal Dreams (1989), London, Abacus, 1993.

-, Complicity (1993), London, Abacus, 1994.

—, Whit (1995), London, Abacus, 1996.

—, The Business (1999), London, Abacus, 2000.

Borges Jorge Luis, Labyrinths (1956-1960), Harmondsworth, Penguin, 1986.

GraY Alasdair, Lanark: A Life in Four Books (1981), London, Paladin, 1989.

Kafka Franz, The Castle (1926), New York, Schocken, 1974.

Peake, Mervyn, Titus Groan (1946), London, Methuen, 1985.

24. Iain Banks, letter to The Guardian, 22/3/03, reprinted at http://www.guardian.co.uk/letters/ story/0,3604,919568,00.html [on-line newspaper], consulted March 2007.

25. Andrew Sparrow, "Stars back attempt to impeach Tony Blair", Daily Telegraph, 25/11/04, reprinted at http://www.telegraph.co.uk/news/main.jhtml?xml=/news/2004/11/25/nimp25.xml \&sSheet=/news/2004/11/25/ixhome.html [on-line newspaper], consulted March 2007.

26. Alan Crawford, "The alternative opening: Radical Scotland declares republic", Sunday Herald, 10/10/2004, p. 4.

27. Alan Bissett, AL Kennedy and Louise Welsh have associated themselves with Faslane 365, while James Kelman, Irvine Welsh, Alasdair Gray and AL Kennedy were all signatories of the "Declaration of Calton Hill". 